\title{
СОЦІАЛЬНО-ПСИХОЛОГІЧНА РЕАБІЛІТАЦІЯ ТА РЕАДАПТАЦІЯ ВОЛОНТЕРІВ: ЕМПІРИЧНА ОЦІНКА ЕФЕКТИВНОСТІ ТЕХНОЛОГІЇ ПАРАДОКСУ
}

Метою дослідження було з'ясувати ефективність застосування технології парадоксу у відновленні жінок-волонтерів - учасниць Школи соціальнопсихологічної допомоги, створеної на базі Чернігівського національного технологічного університету. На основі результатів дослідження зроблено висновок про набуття жінами-волонтерами вмінь та навичок трансформації негативних станів в особистісний досвід, опанування ними засобів психологічної само- та взаємодопомоги, досягнення позитивних змін щодо якості їхнього життя. Емпірично підтверджено позитивну динаміку, а саме зменшення показників посттравматичних станів та порушень адаптивності після завершення занять. Самооцінка учасницями дослідження досягнутих результатів дає підстави говорити про покращення якості їхнього сімейно-родинного життя та взаємодії iз зовнішнім соціальним оточенням як безпосередньо після завершення занять, так і протягом подальших трьох місяців після закінчення Школи. Звертається увага на результати останнього опитування, яке проводилося через три місяці після завершення занять: на тлі покращення якості життя жінок-волонтерів при порівнянні симптоматики ПТСР, адаптивності волонтерок та самооцінки зміни якості життя зафіксовано, однак, відносне зростання показників ПТСР та випадків порушення адаптивності. Таку симптоматику можна пояснити впливом започаткованих у процесі навчання особистісних змін, набуттям жінками більшої суб'єктності, самостійності і відповідальності за власне життя. Саме ці зміни розглядаються як основна причина порушення попереднього, звичного балансу в стосунках із близьким та зовнішнім соціальним середовищем. У зв'язку з цим визнається недостатність зв'язку жінок-волонтерів із викладачами Школи та навчальною групою протягом трьох місяців після завершення занять, адже саме цей зв'язок забезпечував стабільність їхньої особистості в умовах змін у стосунках із своїм сімейно-родинним та соціальним оточенням під час занять. Проведене дослідження засвідчило необхідність розроблення більш ефективних засобів підтримки і соціально-психологічного супроводу жінокволонтерів у процесі їх переходу до самостійного життя в нових для них умовах, забезпечення сталості та гармонійності їхньої особистості в контексті внутрішніх і зовнішніх змін.

Ключові слова: технологія парадоксу, соціально-психологічна реабілітація, реадаптація, волонтери.

B. P. Lazorenko

\section{PSYCHOSOCIAL REHABILITATION AND READAPTATION OF VOLUNTEERS: AN EMPIRICAL EVALUATION OF THE PARADOX TECHNOLOGY EFFICIENCY}

The purpose of the research was to find out the effectiveness of using the paradox technology in the female volunteers restoring, which were the participants 
of the School of Psychosocial Assistance to ATO veterans, members of their families, volunteers and internally displaced persons based on Chernihiv National Technological University. During the studying volunteers got the skills and abilities to transform their negative states into personal experience, mastered the means of psychological self and mutual assistance and achieved positive changes in the quality of their life. There were empirically confirmed the dynamics and decreases of posttraumatic conditions and adaptive disorders after completion of study. According to the self-assessment of the achieved results after the completion of the classes, and within three months after the end of the School, the quality of their family life and interaction with the external social environment improved significantly. However, according to the latest survey, which was conducted three months after the completion of studying, despite of improving their quality of life, comparing the empirical results of PTSD screening, volunteer's adaptability and self-assessment of quality of life changes; there was a relative increase in PTSD symptoms and abnormalities of adaptability. This increase in symptoms is attributed to the influence of personal changes that have been initiated in the learning process. Volunteers gain greater subjectivity, autonomy and responsibility for their own lives. The indicated changes have led to a violation of the previous habitual balance in relations with their families and external social environment. Also the lack of communication between the volunteers and the teachers of the School and the study group during the three months after the completion of classes determined instability of their personalities in condition of changes in relations with their families and social environment. Such communication was ensured in a proper way during the classes. The study showed the need to develop more effective means of volunteers' psychosocial support in their transition to independent living in new conditions for them, ensuring the sustainability and harmony of their personalities in condition of internal and external changes in their lives.

Key words: paradox technology, psychosocial rehabilitation, re-adaptation, volunteers.

Постановка проблеми. Реабілітація та реадаптація особистості, яка переживає наслідки травматичних подій, $є$ актуальним завданням сьогодення в умовах тривання воєнної агресії Російської держави проти України. Як правило, основна увага дослідників спрямована на психологічну реабілітацію та реадаптацію військових, ветеранів АТО, і значно менше уваги приділяється волонтерам. Унаслідок повної самовіддачі, глибокої емпатії багато хто з них потерпає наразі від психотравм, порушень адаптивності та психоемоційного виснаження. Тому розроблення і впровадження ефективних програм психологічної реабілітації та реадаптації волонтерів $є$ актуальною суспільною проблемою.

Аналіз останніх досліджень і публікацій. Оскільки волонтерство $\epsilon$ надзвичайно поширеним суспільним рухом у багатьох зарубіжних країнах, а завдяки цьому досить авторитетно представленим у системі $\mathrm{OOH}$, його дослідженню сьогодні приділяється значна увага. Так, Інститут волонтерських досліджень Великобританії (NCVO) досліджує, як участь у волонтерській діяльності впливає на здоров'я самих волон- 
терів і користувачів медичних послуг [1]. Зарубіжними колегами розроблено, зокрема, програму відновлення фахівців і волонтерів, які працюють у сфері психосоціальної допомоги психічно хворим пацієнтам [2]. Однак волонтерський рух в умовах гібридної війни в Україні суттєво відрізняється від діяльності зарубіжних волонтерів. Саме тому постала нагальна потреба в розробленні власних, вітчизняних, програм комплексного відновлення волонтерів. Лідери волонтерського руху мали цілком слушні підстави зауважувати, що “з часом і для волонтерів потрібно буде проводити психологічну реабілітацію, повертати їх до звичного, довоєнного життя" [3]. У відповідь на цю потребу в Україні з'явилися пілотні програми психологічної реабілітації та підтримки для волонтерів [4; 5], для них проводяться майстер-класи психосоціальної реабілітації [6]. У цілому гостро бракує емпіричних досліджень ефективності реабілітаційних та реадаптивних технологій, зокрема технологій відновлення якості життя.

3 огляду на попередній досвід надання психологічної допомоги учасникам Революції Гідності ми розробили концепцію відновлення особистості, яка постраждала від психотравматичних наслідків воєнних дій. На основі цієї концепції створено відповідний технологічний комплекс, ядро якого становить технологія парадоксу. Ця технологія передбачає актуалізацію механізму парадоксальної реакції з подальшим спонтанно-конструктивним переживанням та засвоєнням негативних станів, їх трансформацією в позитивний особистісний досвід. Технологію в рамках зазначеного комплексу було використано для проведення на базі Чернігівського національного технологічного університету (спільно з К. Кальницькою) Школи соціально-психологічної допомоги ветеранам АТО, членам сімей загиблих, ВПО та волонтерам [7].

Не вирішені раніше частини загальної проблеми. Як показує наш досвід, у суспільстві наразі $€$ запит на розроблення комплексів методик для емпіричного дослідження ефективності реабілітаційних та реадапційних технологій відновлення волонтерів. Такі методики потрібні для того, щоб можна було оцінити, “виміряти” зміни якості їхнього життя, а також, беручи до уваги специфіку діяльності волонтерів в умовах гібридної війни, належним чином удосконалити наявні реабілітаційні та реінтеграційні програми.

Мета статті: висвітлення результатів емпіричного дослідження, у ході якого визначалась ефективність застосування технології парадоксу в реабілітації і реадаптації волонтерів під час проведення Чернігівської школи соціально-психологічної допомоги (далі - Школи) та за допомогою комплексу відповідних діагностичних опитувальників 3'ясовувалися зміни якості їхнього життя.

Виклад основного матеріалу дослідження. Заняття Школи проводилися на добровільний та безоплатній основі на базі зазначеного 
університету. Усього було проведено 12 занять по 3 навчальні години по одному заняттю на тиждень протягом трьох місяців з грудня 2017-го по лютий 2018 року. Процес навчання передбачав індивідуальну та групову роботу, виконання домашніх завдань на засвоєння навичок саморегуляції психоемоційних станів, участь у групових волонтерських заняттях у період між тижневими сесіями. Відтак із загальної кількості учасників Школи (волонтерів) для нашого дослідження ми обрали три кейси жінок-волонтерів: мати учасника АТО; жінка, яка має рідних, котрі брали участь у воєнних діях; дружина учасника АТО.

Основні очікування волонтерок на початку занять були такі: “вийти 3 депресії, підвищити кваліфікацію, навчитися більш якісно допомагати бійцям, а також стабілізувати свій психологічний стан”. Важливими завданнями, які ставили перед собою організатори Школи щодо іiі учасників, були: зменшення напруги посттравматичних станів волонтерів; поліпшення їхньої проактивної адаптивності щодо своїх особистих та соціальних умов життя, покращення якості життя, а також набуття учасниками навичок застосування технології парадоксу та інших технологій реабілітації і реадаптації як засобів самодопомоги і первинної психологічної допомоги тим, хто цього потребує. Емпіричне дослідження мало також і ще одне окреме завдання: за допомогою комплексу діагностичних опитувальників визначити ефективність засвоєння цієї технології на початку занять Школи, по закінченні тримісячного терміну після завершення занять і втретє - через три місяці по закінченні Школи.

Як дослідницький інструментарій було використано: опитувальник “Перелік симптомів ПТСР" для української популяції (адаптація О. Хаустової, Л. Трачук, В. Безшейка) [8]; багаторівневий особистісний опитувальник “Адаптивність” А. Маклакова і С. Чермяніна [9] та авторський опитувальник самооцінки зміни якості життя учасників Школи соціально-психологічної допомоги.

Опитувальником "Перелік симптомів ПТСР" ми скористалися для того, щоб з'ясувати наявність в учасників Школи відповідних симптомів та простежити зміни цих симптомів у процесі занять. Перелік містив 20 питань, які відображали відповідні кластери симптомів ПТСР: опис травматичної події, симптоми інтрузії (5 запитань), симптоми уникнення (2 запитання), негативні думки та емоції (7 запитань), симптоми надмірної реактивності (6 запитань). Опитуваний мав зазначати в балах величину прояву симптому, оцінити за кожним питанням свою відповідь щодо прояву симптому в балах від 0 до 4. Потім підраховувалася загальна сума балів: мінімально можливий бал - 0, максимально можливий - 80. Схильність до ПТСР діагностувалася в тому разі, коли загальна кількість набраних балів сягала 33 і більше.

Щоб визначити стан адаптивного потенціалу учасників Школи, ми застосували багаторівневий опитувальник “Адаптивність”. Він міс- 
тить 165 питань і має чотири структурних шкали, а саме: оцінювання достовірності відповідей досліджуваних та оціювання їхньої поведінкової регуляції; визначення комунікативного потенціалу та рівня моральної нормативності. Шкала достовірності дає змогу оцінити ступінь об’єктивності відповідей; за цією шкалою відповіді всіх трьох досліджуваних було оцінено як достовірні. Поведінкова регуляція характеризує здатність особистості керувати взаємодією із зовнішнім середовищем; комунікативний потенціал визначає іiі спроможність будувати позитивні відносини з іншими людьми, уміння налагоджувати контакт і взаєморозуміння з оточенням; моральна нормативність характеризує рівень засвоєння особистістю загальних морально-етичних норм суспільства та їх дотримання в ході взаємодії із соціальним оточенням.

3'ясовуючи стан адаптивного потенціалу учасників Школи, ми користувалися “сирими” балами і не переводили їх у стени, оскільки для нас важливо було порівняти дані за кожною шкалою на початку занять Школи, по пї завершенні і через три місяці після завершення занять. Однак щоб краще орієнтуватися щодо загальної оцінки фактичних рівнів адаптивності досліджуваних волонтерок (які вони мали на початку занять, по їх закінченні і через три місяці), ми використали інтегративний показник особистого адаптивного потенціалу (далі ОАП), запропонований розробниками цього опитувальника. Показник ОАП визначається за сумою балів поведінкової регуляції, комунікативного потенціалу та моральної нормативності на час проведення опитування.

Використання перших двох опитувальників на початку занять дало нам також змогу визначити провідні негативні стани волонтерів, а саме ті, які в першу чергу потребують опрацювання. Опитувальник самооцінки зміни якості життя учасників ми розробили, щоб отримати інформацію від учасників Школи про ступінь оволодіння ними запропонованою технологією парадоксу та іншими психотехніками психологічної самодопомоги і допомоги своїм близькими та особам, які іiі потребують. Першими двома опитувальниками ми скористалися тричі: на початку занять, по їх завершенні та через три місяці після закінчення основного курсу Школи. Опитування щодо зміни якості життя волонтерів ми проводили двічі: по закінченні занять і через три місяці по завершенні Школи.

Узагальнені емпіричні дані дослідницьких кейсів трьох жінокволонтерів (B1, В3, В3) ми спробували представити в графічній формі (рис.). Уточнимо відтак, що "ПТСР" - це дані проявів симптомів посттравматичного розладу, до яких належать: симптоми інтрузії (сим. інт.); симптоми уникнення (сим. уник.); негативні думки і емоції (нег. д. і м.); надмірна реактивність (над. реаг.). "Адаптивність” визначає показники порушень адаптивності, серед яких: поведінкова регуляція (пр.); комунікативний потенціал (кп); рівень моральної нормативності (мн.). 


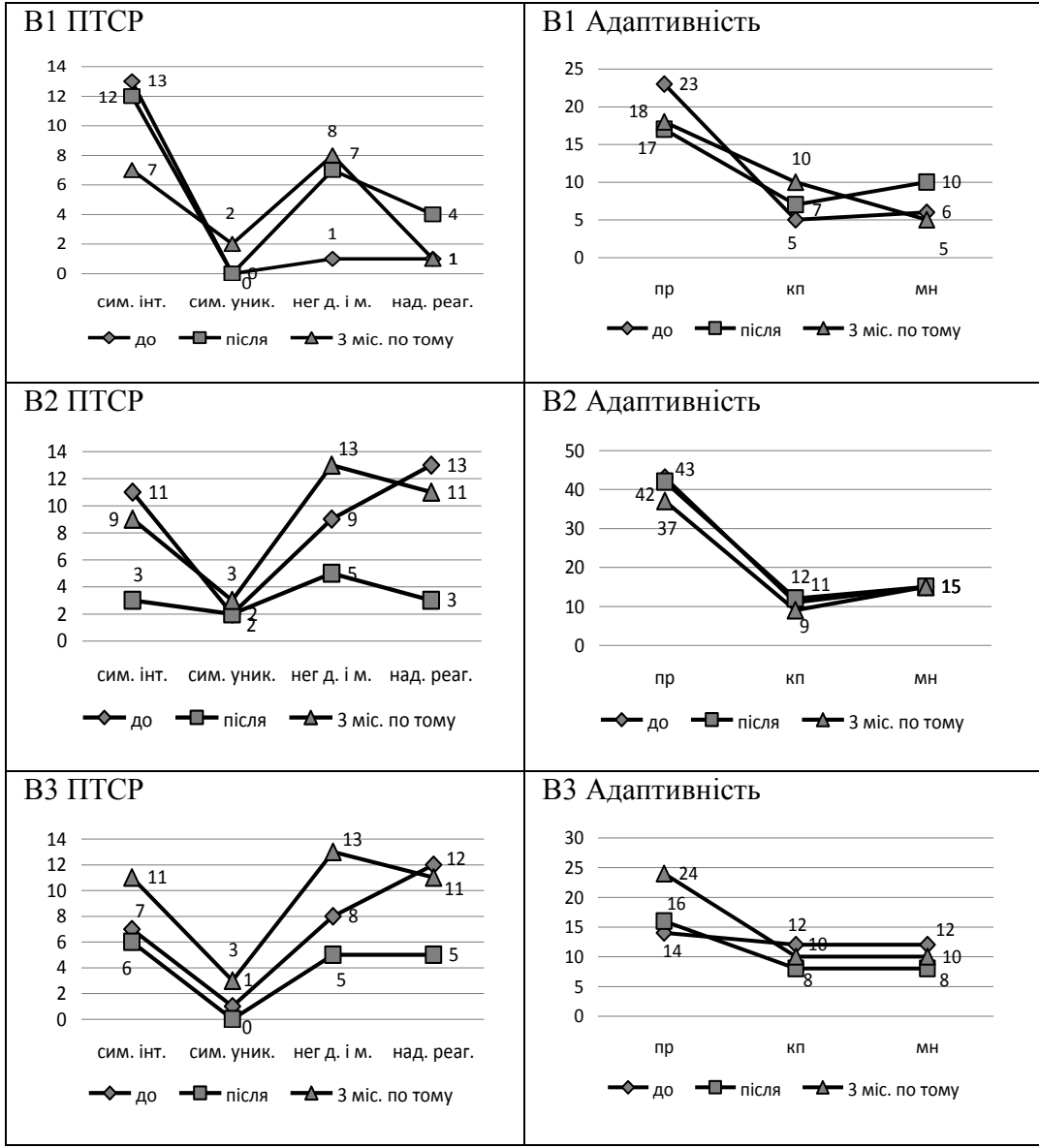

Рис. Кількісні значення симптомів ПТСР і показників порушень адаптивності досліджуваних волонтерок (у балах)

Загальні криві графіків, побудованих на основі отриманих результатів дослідження за переліком симптомів ПТСР, мають схожий вигляд. Більша схожість спостерігається між динамікою В2 і динамікою В3. У В1 за всіма трьома графіками найвищі показники мають симптоми інтрузії, а найнижчі - симптоми уникнення. У В2 і В3 найвищих значень досягають показники негативних думок та емоцій, найнижчі значення у симптомів уникнення. Порівняння трьох графіків динаміки показників симптомів ПТСР показує, що після проведення занять ці показники у В2 і В3 у цілому зменшуються, а через три місяці по завершенні дещо підвищуються, але в цілому вони нижчі, ніж були на початку 
занять. У В1 зазначені показники є найнижчими на початку занять, підвищуються по їх закінченні і дещо зменшуються порівняно з попередніми, отриманими під кінець проведення Школи.

Більш детальний аналіз даних показує, що у В1 симптоматика інтрузії зменшилася з 13 балів на початку занять до 12 після їх закінчення і до 7 балів - через три місяці після завершення роботи Школи. Симптоми уникнення, які не проявлялися на початку і по завершенні занять, зросли на 2 бали через три місяці. Показники негативних думок та емоцій зросли 31 бала на початку занять до 7 балів після їх завершення і до 8 - через три місяці, що, на нашу думку, свідчить про актуалізацію пошукової діяльності волонтерки в умовах переходу до звичайного життя. Показник надмірної реактивності теж зріс з 1 бала на початку занять до 4 балів по їх завершенні і знову повернувся, згідно 3 даними останнього опитування, до вихідних значень (1 бала).

Загальна сума показників симптоматики ПТСР у респондентки В1 має таку динаміку: 15 балів - перше опитування, 23 бали - друге i 18 балів - третє опитування. Це, на нашу думку, свідчить про певні зміни в способі та якості життя В1, пошук нею нових життєвих сенсів. У цілому інтегративний показник схильності до ПТСР у В1 майже удвічі нижчий за базовий показник відліку його наявності.

У респондентки В2 симптоми інтрузії зменшилися з 11 до 3 балів, потім зростали протягом трьох місяців поспіль до 9 балів. Симптоми уникнення і на початку, і по завершенні занять становили 2 бали, а через три місяці вони трохи зросли - до 3 балів. Показник негативних думок і емоцій на початку дослідження становив 9 балів, а по завершенні занять зменшився до 5 балів. Через три місяці він зріс до 13 балів. Вважаємо, що це свідчить про значні зміни в особистому та соціальному житті волонтерки, які вона оцінила як позитивні за опитувальником зміни якості життя.. Симптоматика надмірної реактивності на початку дослідження становила 13 балів, по завершенні занять вона знизилася до 3 , а через три місяці знову зросла до 11 балів. Таке зростання також пов'язане із змінами в способі життя волонтерки та в його якості. Загальна сума показників симптоматики ПТСР у В2 змінювалася так: 35 балів - перше опитування, 13 балів - друге і 36 балів - останнє. Тобто загальний показник симптоматики повернувся на попередній рівень при дещо зміненій конфігурації своїх складових і на дещо (на 2 бали) перевищив межу схильності до ПТСР. Пояснити таку динаміку симптомів ПТСР можна, коли звернутися до результатів, отриманих за допомогою опитувальника якості життя (про це йтиметься нижче).

У респондентки В3 значення симптомів інтрузії на початку занять становили 7 балів, під кінець вони зменшилися до 5, а через три місяці знову зросли до 11 балів. Щодо симптомів уникнення, які в цілому залишилися на низькому рівні, спостережено незначні коливання: на 
початку дослідження вони становили 1 бал, по завершенні - 0 і під кінець дослідження - 3 бали. Показники симптомів негативних думок та емоцій на початку дослідження становили 8 балів, під кінець занять вони зменшилися до 5, а на кінець останнього дослідження знову зросли до 13 балів. Показники надмірної реактивності мали таку динаміку: на початку дослідження вони становили 12 балів, під кінець занять - 5 балів, а по завершенні дослідження зросли майже до початкового рівня i досягли 11 балів. Загальна сума показників симптоматики ПТСР у В3 така: 26 балів - перше опитування, 16 балів - друге і 38 балів - третє. Як бачимо, останній показник засвідчив зростання показників майже удвічі порівняно з попереднім та перевищив межу схильності до ПТСР на 5 балів. Така різка зміна показника симптоматики ПТСР зумовлена особистісними змінами у В3, загостренням її подружніх стосунків та пошуком досліджуваною нового балансу у своїх партнерських взаєминах.

Розгляньмо відтак дані, отримані в результаті застосування багаторівневого опитувальника “Адаптивність”. У респондентки В1 показник порушення поведінкової регуляції на початку дослідження становив 23 бали, по закінченні занять він знизився до 18 балів, а під кінець дослідження зріс до 19 балів. Рівень порушень комунікативного потенціалу становив 3 бали на початку, зріс до 7 балів після закінчення занять і ще зріс до 10 балів, за даними останнього дослідження. Рівень порушень моральної нормативності на початку дослідження становив 6 балів, далі зріс до 10 після завершення занять і знизився до 5 балів за результатами останнього дослідження. Загалом у В1 показник ОАП змінювався протягом періоду дослідження так: на початку занять він становив 44 бали, 34 - по їх закінченні і 23 бали - по завершенні дослідження. За динамікою цих показників В1 перемістилася з групи осіб із зниженою адаптацією у групу задовільної адаптації.

У респондентки В2 рівень поведінкової регуляції на початок занять становив 43 бали, по їх закінченні він неістотно знизився - до 42 балів i, за даними останнього дослідження, знову зменшився до 37 балів. Рівень комунікативного потенціалу на початку дослідження становив 11 балів, по закінченні занять трохи зріс - до 12 балів, а під кінець дослідження опустився до 9 балів. Рівень моральної нормативності залишався стабільним (15 балів) протягом усього часу дослідження. Отже, респондентка В2 за показниками ОАП (69 балів - на початку занять і по їх завершенні, 61 бал - за даними останнього опитування) належить до групи осіб із зниженою адаптацією, проте з огляду на виявлену динаміку можемо говорити про ії наближення до групи задовільної адаптації.

У респондентки В3 поведінкова регуляція на початку занять мала значення 24 бали, по їх завершенні - 14 балів і під кінець дослідження - 16 балів. Комунікативний потенціал та моральна нормативність 
мали схожу динаміку: на початку дослідження їхні показники становили 12 балів, по завершенні занять - 8 балів, а під кінець дослідження - 10 балів. Показники ОАП та їхня динаміка (38 балів на початку занять, 32 по їх завершенні і 44 бали - за даними останнього опитування) свідчать про переміщення волонтерки в рамках групи осіб із зниженою адаптацією в бік групи задовільної адаптації.

Важливою для розуміння динаміки показників ПТСР та адаптивності волонтерок $є$ їхня самооцінка зміни якості життя протягом періоду занять і через три місяці самостійного життя поза систематичними заняттями й спілкуванням із керівникам Школи та іншими учасниками.

По завершенні занять волонтерка В1, мати учасника АТО, зазначила, що їі фізичне і психологічне самопочуття значно покращилось. Також значно поліпшилися їі стосунки з колегами і керівництвом, вдалося порозумітися зі своїм Я, пізнати свої почуття та ставлення до інших. Вона впевнена, що зможе користуватися набутими навичками самодопомоги й допомагати своїм близьким та рідним, а також певною мірою зможе бути корисною для своїх друзів, колег, інших людей, які цього потребують. Через три місяці по завершенні навчання іiі фізичне і психологічне самопочуття покращилось у цілому помірно. Вона стала більш спокійною, “полюбила ще більше життя та своїх знайомих”, у неї покращилися стосунки з колегами і керівництвом на роботі. Свою здатність користуватися навичками самодопомоги, допомоги близьким та іншим людям жінка оцінила як “скоріше так”.

У волонтерки В2 по завершенні занять значно покращилося фізичне і психологічне самопочуття: “зменшився головний біль та біль у ногах, ніби впав «лантух» зі спини; з'явилася легкість у тілі, загалом стала більш спокійною і врівноваженою, почала приділяти собі більше уваги". Покращилися стосунки з чоловіком і дітьми: “чоловік став мене помічати, а діти згадали про мене як про матір, а не просто як про гаманець”. Також значно покращилися стосунки з керівництвом і колегами на роботі: “почали звертатися до мене по батькові”. Друзі й колеги відзначили, що в неї відбулися за цей час значні зміни на краще. Через три місяці по завершенні занять волонтерка зауважила значне покращення фізичного здоров'я і сну. Також значно поліпшився психологічний стан, поглибилися врівноваженість і спокій, гармонізувалися стосунки з чоловіком, дітьми та матір'ю. Що ж до стосунків у робочому колективі, де працювала жінка, то іiі життя кардинально змінилось у кращий бік. За час, що минув після закінчення занять, волонтерка переконалась, що зможе успішно користуватися набутими навичками самодопомоги і допомоги іншим людям.

По завершенні занять у волонтерки В3, дружини учасника бойових дій, значно покращилося фізичне і психологічне самопочуття. Вона стала більш спокійною та врівноваженою, більш упевненою в собі. У 
неї з'явилося відчуття, що все добре і “багато з того, що було важливим раніше, втратило своє значення”. Ї̈̈ ставлення до батьків, чоловіка, дітей значно покращилось. Вона зазначила, що перестала адресувати, i вони заспокоїлися. Її ставлення до керівництва, колег, а також їхнє ставлення до неї істотно покращилось: “я згадала, що в мене є колеги”. Вона впевнена, що зможе користуватися набутими навичками самодопомоги, допомагати своїм рідним і близьким, а також своїм друзям, колегам і тим, хто цього потребує. Через три місяці по завершенні занять фізичне і психологічне почуття волонтерки покращилося помірно, iii ставлення до дітей і дітей до неї стало більш глибоким. Також значно покращилися іiї стосунки з колегами, вона стала більше цінувати своїх співробітників. Завдяки участі у Школі змінилися погляди на себе, світ, родину. Що ж до самодопомоги, здатності допомагати близьким та іншим людям, які цього потребують, то ііі впевненість залишилася такою ж, як і після завершення навчання. Жінка також усвідомлює необхідність поширення набутих знань і навичок за принципом "рівний рівному".

Висновки. Згідно з результатами емпіричного дослідження кейсів волонтерок, які брали участь у заняттях Школи, виявлено ефективність застосування технології парадоксу в контексті реінтеграційних та реабілітаційних технологій відновлення в процесі опанування учасницями запропонованої навчальної програми. Виявлено, що в цілому жінки набули умінь та навичок трансформації негативних станів в особистісний досвід, опанували засоби надання й отримання первинної психологічної допомоги. Емпірично підтверджено позитивну динаміку та зменшення показників посттравматичних станів і порушень адаптивності після завершення занять.

Згідно із самооцінкою досягнутих результатів суттєво покращилася якість сімейно-родинного життя жінок-волонтерів та їхня взаємодія із зовнішнім соціальним оточенням як по закінченні занять, так і протягом трьох місяців після завершення Школи. Проте порівняння емпіричних результатів скринінгу ПТСР, адаптивності волонтерок та самооцінки зміни якості їхнього життя показало відносне підвищення показників симптоматики ПТСР та порушень адаптивності згідно 3 останнім опитуванням на тлі покращення якості їхнього життя.

3 огляду на нашу гіпотезу таке підвищення симптоматики пояснюється продовженням і закінченням особистісних змін, започаткованих у процесі навчання, набуттям волонтерками більшої суб'єктності, самостійності і відповідальності за власне життя. Такі зміни зумовлюють порушення попереднього, звичного балансу в стосунках із близьким та зовнішнім соціальним середовищем. Звернуто також увагу на недостатність безпосереднього зв'язку волонтерок із викладачами Школи та навчальною групою протягом трьох місяців після завершення занять, 
що забезпечував стабільність їхнього стану в умовах особистісних змін і змін у стосунках зі своїм оточенням під час занять.

Проведене дослідження засвідчило необхідність розроблення більш ефективних засобів підтримки і соціально-психологічного супроводу жінок-волонтерів у їхньому переході до самостійного життя в нових для них умовах i, беручи до уваги динаміку внутрішніх і зовнішніх змін їхнього життя, забезпечення сталості та гармонійності їхньої особистості.

\section{Список використаних джерел}

1. Volunteering and Mental Health: A Review of the Literature (2004). Retrieved from https://www.energizeinc.com/sites/default/files/volunteeringandmentalhealth.pdf.

2. Farkas, M., Hutchinson, D., Forbess, R., Restrepo-Toro, M., \& Russinova, Z. Recovery Promoting Competencies Toolkit. (2018). Retrieved from https://cpr. bu.edu/develop/toolkit.

3. Гвоздяр, А. (2017). 3 часом волонтерам знадобиться психологічна реабілітація. Взято 3 https://glavcom.ua/publications/anna-gvozdyar-z-chasomvolonteram-znadobitsya-psihologichna-reabilitaciya-425940.html.

4. РадіоДень. Психологічна реабілітація волонтерів (2018). Взято 3 https://www.youtube.com/watch?v=dZa2e-DJVhA.

5. У ДніпроОДА стартував черговий курс тренінгів з психологічної реабілітації (2018). Взято $3 \mathrm{https} / / /$ adm.dp.gov.ua/ua/news/u-dniprooda-startuvav-chergovijkurs-treningiv-z-psihologichnoyi-reabilitaciyi.

6. Як розуміти $і$ переживати свої емочії та почуття. (2016). Взято 3 https://business.facebook.com/kmarehab/?hc_ref=ARTgA.

7. Lazorenko, B., \& Kalnytska, K. (2018). Readaptation of ATO Veterans and their Wives: Experience of Psychosocial Assistance School. Mental Health Global Challenges XXI Century, (2), 59. Retrieved from https://www.mhgc21.org/.

8. Безшейко, В. (2016). Адаптація Шкали для клінічної діагностики ПТСР та опитувальника "Перелік симптомів ПТСР" для української популяції. Психосоматична медицина та загальна практика, (1). Взято з https://uk.emedjournal.com/index.php/psp/article/view/8.

9. Маклаков, А. Г., \& Чермянин, С. В. (2006). Многоуровневый личностный опросник. Адаптивность (МЛО-АМ). В Д. Я. Райгородский (Ред.), Практическая психодиагностика. Методики и тестьл. Самара: Бахрах-М.

\section{References}

1. Volunteering and Mental Health: A Review of the Literature (2004). Retrieved from https://www.energizeinc.com/sites/default/files/volunteeringandmentalhealth.pdf.

2. Farkas, M., Hutchinson, D., Forbess, R., Restrepo-Toro, M., \& Russinova, Z. Recovery Promoting Competencies Toolkit. (2018). Retrieved from https://cpr. bu.edu/develop/toolkit.

3. Hvozdiar, A. (2017). Z chasom volonteram znadobytsia psykholohichna reabilitatsiia [Over time, volunteers will need psychological rehabilitation.]. Retrieved from https://glavcom.ua/publications/anna-gvozdyar-z-chasomvolonteram-znadobitsya-psihologichna-reabilitaciya-425940.html/ (ukr). 
4. RadioDen. Psykholohichna reabilitatsiia volonteriv [RadioDay. Psychological rehabilitation of volunteers]. (2018). Retrieved from https://www.youtube.com/ watch?v=dZa2e-DJVhA (ukr).

5. U DniproODA startuvav cherhovyi kurs treninhiv z psykholohichnoi reabilitatsii [DniproODA The next course of psychological rehabilitation training has started] (2018). Retrieved from https://adm.dp.gov.ua/ua/news/u-dniproodastartuvav-chergovij-kurs-treningiv-z-psihologichnoyi-reabilitaciyi (ukr).

6. Yak rozumity i perezhyvaty svoi emotsii ta pochuttia [How to understand and experience your emotions and feelings] (2016). Retrieved from https://business. facebook.com/kmarehab/?hc_ref=ARTgA (ukr).

7. Lazorenko, B., \& Kalnytska, K. (2018). Readaptation of ATO Veterans and their Wives: Experience of Psychosocial Assistance School. Mental Health Global Challenges XXI Century, (2), 59. Retrieved from https://www.mhgc21.org/.

8. Bezsheiko, V. (2016). Adaptatsiia Shkaly dlia klinichnoi diahnostyky PTSR ta opytuvalnyka "Perelik symptomiv PTSR" dlia ukrainskoi populiatsii [Scale Adaptation for Clinical Diagnostic PTSD and questionnaire "Checklist of PTSD Symptoms" for the Ukrainian population]. Psykhosomatychna medytsyna ta zahalna praktyka [Psychosomatic Medicine and General Practice], (1). Retrieved from https://uk.e-medjournal.com/index.php/psp/article/view/8 (ukr).

9. Maklakov, A. G., \& Chermyanin, S. V. (2006). Mnogourovnevyy lichnostnyy oprosnik. Adaptivnost (MLO-AM) [Multi-level personal questionnaire. Adaptability (MLE-AM)]. In D. Ya. Raygorodskiy (Ed.), Prakticheskaya psikhodiagnostika. Metodiki $i$ testy [Practical psychodiagnosis. Methods and tests]. Samara: Bakhrakh-M Publ. (rus).

(С) Лазоренко Б. П. 